\title{
旅游地交通服务功能与旅游强度协调时空分异特征 以云南省为例
}

\author{
郭向阳 ${ }^{1,2}$, 穆学青 ${ }^{3}$, 明庆忠 ${ }^{4}$, 丁正山 ${ }^{1,2}$ \\ (1. 南京师范大学地理科学学院, 南京 $210023 ; 2$. 江苏省地理信息资源开发与利用 \\ 协同创新中心, 南京 $210023 ; 3$. 云南师范大学旅游与地理科学学院, 昆明 650500 ; \\ 4. 云南财经大学旅游文化产业研究院, 昆明 650221)
}

\begin{abstract}
摘要: 以典型旅游地云南省为研究案例地, 基于高德交通大数据、电子地图 POI等多源数据, 通 过构建综合交通服务功能与旅游强度概念模型, 采用改进的 TOPSIS 法、耦合协调模型和 Tobit 模型, 从时空视角审视交通服务功能与旅游强度协调空间分异特征及不同交通服务功能对旅 游强度的贡献效应。结果表明: (1)2006-2016年, 云南省各州市综合交通服务功能与旅游强 度协同效应逐渐凸显, 协调主导类型由 “濒临失调型” 跃迁为“初级协调型”。(2)综合交通服务 功能与旅游强度协调度总体格局呈 “中部高, 东西两侧和南北两翼低” 的空间布局态势, 且东西 分异剧烈, 南北变化相对平稳; 区域差异特征呈现 “滇中 $>$ 滇东南 $>$ 滇西南 $>$ 滇西 $>$ 滇西北 $>$ 滇东北”俱乐部趋同空间态势; 不同交通方式与旅游强度协调度空间分异特征存在显著差异。 (3)公路、铁路、航空对旅游强度的贡献效应表现为“航空运输 > 公路交通 > 铁路交通”的不均 衡特征; 旅游地居民收人、旅游资源禀赋、市场化程度均对旅游强度呈现正向促进效应, 但对外 开放水平较低一定程度上制约了区域旅游强度提升。
\end{abstract}

关键词: 多源数据;交通服务功能;旅游强度;耦合协调模型;云南省

综合交通设施是连接旅游客源地与目的地间的通道与桥梁，能有效促进区域间生产要 素传导流动，对区域旅游空间结构形成、优化发挥着直接动力和引擎作用 ${ }^{[1]}$ 。旅游经济作 为国民经济重要组成部分，其发展速度和质量对区域综合交通系统具有高度依赖性。综合 交通设施与旅游发展关系十分密切，但受制于区域发展不平衡与不充分，不同地方综合 交通设施与旅游发展空间匹配性迥异，尤其对处于西南边疆旅游资源本底优势明显、旅 游空间结构的研究相对薄弱且公共服务设施首先要解决交通这一问题的典型旅游地云南 省而言更为明显。探索其综合交通系统与旅游强度耦合作用机制、协调分异特征，并探 究不同交通类型与旅游强度协调空间分异特征，有利于凸显交通在边疆民族地区旅游扶 贫中的功能, 可为目的地旅游基础设施优化和旅游服务模式的创新提供指导; 同时对丰 富完善旅游交通地域分异规律的研究内容与方法具有重要意义。与此同时, 地理大数据 应用方兴未艾, 已成为地理学规律发现的重要基础与地理科学现象发现的潜在推动力 ${ }^{[2]}$ 。 因此，基于多源数据科学揭示旅游地交通设施与旅游强度耦合互馈效应是一项重要议题。

收稿日期：2019-04-11；修订日期：2019-06-11

基金项目：国家自然科学基金项目（41671147，41361037); 云南省重大招标项目（ZDZB201802）；云南哲社基地重 点项目 (JD2017ZD02)

作者简介: 郭向阳 (1990-), 男, 河南开封人, 博士研究生, 研究方向为旅游地理与旅游规划。 E-mail: 1042961349@qq.com

通讯作者：明庆忠（1963- ), 男, 湖北黄冈人, 博士, 教授, 博士生导师, 研究方向为区域旅游发展与管理。 E-mail: mingqingzhong01@163.com 
旅游业作为区域经济的重要组成部分，在交通网络不断优化背景下，交通与旅游业 关系研究业已成为学术界关注的重点和热点问题。国内外学者取得了诸多卓有特色的成 果, 国外研究集中在交通对旅游目的地优化影响 ${ }^{[3,4]}$ 、公共交通系统、高铁等对城市旅游 空间结构的驱动效应 ${ }^{[5]}$ 、航空运输对旅游空间拓展与驱动效应 ${ }^{[6,7]}$ 、旅游者交通模式选择行 为 ${ }^{[8,9]}$ 、旅游交通政策与趋势研究 ${ }^{[10,11]}$ 等。国外研究为国内研究提供了重要理论借鉴, 国内 集中在交通网络对目的地旅游空间结构优化 ${ }^{[12-14]}$ 、交通对区域旅游可达性及旅游联系强度 影响 ${ }^{[15-17]}$ 、交通网络影响下的区域旅游效率变化 ${ }^{[18-20]}$ 、交通与旅游绩效耦合 ${ }^{[21-23]}$ 等方面; 在

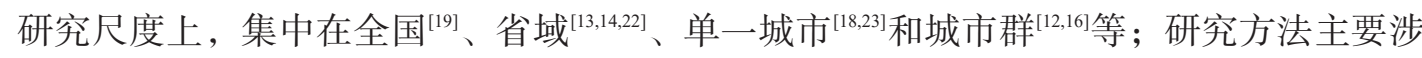
及到改进的场强模型 ${ }^{[13]}$ 、Tobit 模型 ${ }^{[18,19]}$ 、耦合协调模型 ${ }^{[1,22,23]}$ 、DEA数据包络分析 ${ }^{[18,20]}$ 、供 给和需求潜力模型 ${ }^{[16]}$ 、ArcGIS 网络分析与成本加权栅格集成法 ${ }^{[15]}$ 、城市吸引力模型 ${ }^{[24,25]}$ 和 整数网络化客流分配模型 ${ }^{[26]}$ 等。综上, 以往研究取得了较为丰硕的成果，为本文及今后 研究奠定了基础，但仍有待完善之处：（1）关于交通网络改善与旅游空间结构优化耦合 机理及两者协调时空分异特征研究较为薄弱, 且鲜有文献基于多源数据基础对两者协调 指数演变分异特征展开剖析;（2）缺乏对欠发达地区交通服务功能驱动旅游空间结构优 化的研究, 尤其是对处于边疆山区云南省旅游发展更需要交通系统支撑，其旅游业对交 通改善响应程度更加强烈。边疆山区云南省交通服务功能与旅游强度协调关系空间分异 特征如何? 不同交通类型对旅游强度驱动效应怎样? 鉴于此, 选取典型山区旅游地云南 省为研究案例地, 揭示交通服务功能与旅游强度空间关系, 具有区域典型性和实证价 值。基于多源数据样本, 在构建综合交通服务功能与旅游强度评价指标体系基础上, 采 用改进的 TOPSIS 方法与耦合协调模型，从时空视角审视交通网络演变与旅游强度空间耦 合分异特征，一方面有利于辨识综合交通服务功能与旅游发展的瓶颈问题，另一方面能 够为区域综合交通系统建设与旅游规划提供借鉴。

\section{1 研究方法与数据来源}

\section{1 综合交通服务功能与旅游发展耦合理论}

耦合（Coupling）是指两个或两个以上系统或运动方式通过各种相互作用而彼此影响 以至联合起来的现象，是在各子系统间的良性互动下，相互依赖、相互协调、相互促进的 动态关联关系 ${ }^{[22,27]}$ 。旅游地交通系统与旅游发展表现为相辅相承、耦合互馈共生关系（图 1)。

交通服务功能对旅游业影响有：（1）交通网络改善能提升旅游地区位可达性 ${ }^{[15,17]}$, 降 低旅游物质流、信息流和旅游客流通勤时间 成本, 增强目的地各旅游节点旅游联系强度; （2）交通站点密度增加、线路网络化、立体 化与智慧化发展, 能降低游客出游 “行游比”, 拓展与延伸旅游目的地客源市场范围 ${ }^{[16]}$, 改善 与优化旅游地旅游客源市场结构;（3）交通 通行规模扩大、通行效率与能力提升、运输 结构优化与功能完善, 能够促进旅游地旅游 资源集群式开发 ${ }^{[22]}$, 将目的地资源本底优势转 化为经济优势, 更好地服务于旅游扶贫;

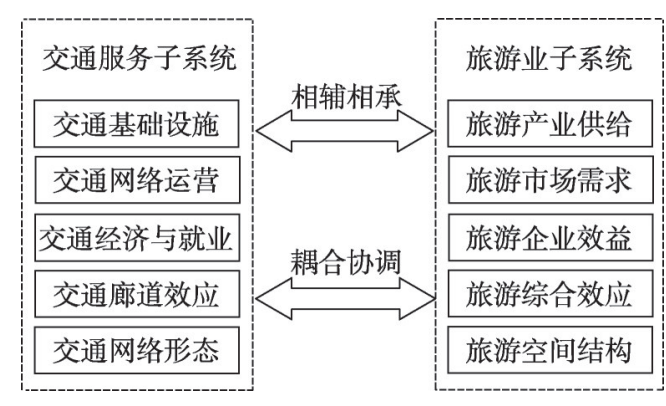

图 1 交通服务功能与旅游业耦合协调机制

Fig. 1 Coupling and coordination mechanism between transportation service function and tourism 
（4）交通换乘便捷度提升能够引致区位条件改善, 促进各类生产要素集聚和地方旅游实

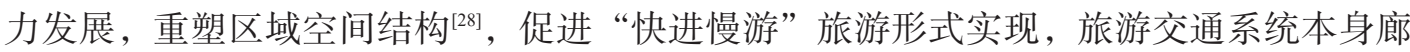
道效应 ${ }^{[27]}$ 与空间溢出效应能加速旅游地产业要素空间传导, 打破区域旅游边界效应, 催 生新的旅游节点, 带动次级旅游节点壮大发展, 促使旅游目的地空间结构形态由孤立节 点向轴线状和网络化结构演变，优化旅游目的地空间紧凑度与空间联系结构模式。

区域旅游发展对交通影响有：（1）旅游地产业要素规模提升，促使区域间旅游产业 要素回环流动及规模效应增强, 迫使交通网络密度与规模扩大, 即旅游发展的 “胁迫效 应” 提升交通运输运行效率与强度 ${ }^{[22]}$ 。(2) 旅游规模与旅游效益扩大为目的地交通网络 建设提供充裕资金支持，而旅游地交通站点优化、规模提升、网络结构与可达性改善又 反作用于旅游客流规模集聚，进而影响其空间扩散流向与流速 ${ }^{[29]}$ 。（3）旅游地吸引物禀 赋与规模性开发能够引导交通站点分布、线路网络延伸与展布范围优化 ${ }^{[14]}$ 。交通网络往 往更趋向于旅游资源富集地区呈轴向展布，将各旅游景区（点）串联形成旅游轴线，逐 渐形成典型旅游地 “点一轴” 发展模式或 “网络化” 交互作用模式。（4）随着旅游地中 心节点壮大与旅游功能要素规模性集聚, 旅游要素流在旅游系统 “推一拉” 模式作用下 易对次级节点形成溢出与扩散效应 ${ }^{[30]}$ ， 区域间旅游要素交换的频率与强度增大，对目的 地交通运输质量、交通经济和交通就业产生正反馈效应。

\section{2 研究方法}

\subsection{1 改进的 TOPSIS 模型}

(1) 熵值法求权重

在利用极差法对原始数据进行无量纲标准化处理基础上，运用熵值法求指标权重。 熵值法既能克服德尔菲法确定权重的主观性, 又能克服复杂巨系统中因指标过多而带来 属性的重复性，适合客观数据和多元化综合指标的评价 ${ }^{[1]}$ 。具体步骤见文献 [22]。

(2) 改进的 TOPSIS 模型

TOPSIS 法是系统工程中有限方案多属性决策分析的一种科学决策技术，其原理是 通过计算备选方案与正、负理想解的相对距离来进行排序优选, 无特别要求样本量的 多少，不受参考序列选择的干扰，具有几何意义直观、信息失真小、运算灵活及应用 领域广等的优点 ${ }^{[32]}$ 。本文采用改进熵权 TOPSIS 法对综合交通服务功能优势度 $Z(y)$ 与旅 游强度 $T(x)$ 进行综合评价。步骤如下:

(1) 利用极差标准化方式进行数据处理, 将标准化后的指标矩阵与熵权法确定的权重 矩阵相乘, 得到加权规范化评价矩阵 $Y$ :

$$
Y=\left[\begin{array}{cccc}
y_{11} & y_{12} & \cdots & y_{1 n} \\
y_{21} & y_{22} & \cdots & y_{2 n} \\
\vdots & \vdots & \vdots & \vdots \\
y_{m 1} & y_{m 2} & \cdots & y_{m n}
\end{array}\right]=\left[\begin{array}{cccc}
r_{11} \cdot \omega_{1} & r_{12} \cdot \omega_{2} & \cdots & r_{1 n} \cdot \omega_{n} \\
r_{21} \cdot \omega_{1} & r_{22} \cdot \omega_{2} & \cdots & r_{2 n} \cdot \omega_{n} \\
\vdots & \vdots & \vdots & \vdots \\
r_{m 1} \cdot \omega_{1} & r_{m 2} \cdot \omega_{1} & \cdots & r_{m n} \cdot \omega_{n}
\end{array}\right]
$$

式中： $r_{m n}$ 表示准化后的第 $m$ 年第 $n$ 个指标; $\omega$ 指权重。

(2) 确定正、负理想解:

$$
\begin{aligned}
& Y^{+}=\max \left\{\left(y_{i j} \mid i=1,2, \cdots, m\right)\right\}(j=1,2, \cdots, n)=\left\{Y_{1}^{+}, Y_{2}^{+}, \cdots, Y_{n}^{+}\right\} \\
& Y^{-}=\min \left\{\left(y_{i j} \mid i=1,2, \cdots, m\right)\right\}(j=1,2, \cdots, n)=\left\{Y_{1}^{-}, Y_{2}^{-}, \cdots, Y_{n}^{-}\right\}
\end{aligned}
$$

式中: $Y^{+}$表示第 $j$ 个指标在 $i$ 年内的最大值, 称 $Y^{+}$是正理想解, 即可选择的最理想方 案; $Y^{-}$表示第 $j$ 个指标在 $i$ 年内的最小值, $Y^{-}$为负理想解, 即最差方案。 
(3) 各指标到正理想解及负理想解的距离:

$$
D_{j}^{+}=\sqrt{\sum_{i=1}^{m}\left(y_{j}^{+}-y_{i j}\right)^{2}} ; D_{j}^{-}=\sqrt{\sum_{i=1}^{m}\left(y_{j}^{-}-y_{i j}\right)^{2}}
$$

式中: $D_{j}^{+}$表示第 $j$ 个指标和 $y_{j}^{+}$的距离 $; D_{j}^{-}$表示第 $j$ 个指标和 $y_{j}^{-}$的距离。

(4.) 计算贴进度:

$$
C_{j}=\frac{D_{j}^{-}}{D_{j}^{+}+D_{j}^{-}}
$$

式中: $C_{j} \in[0,1]$, 能综合表征 $D_{j}^{+}$和 $D_{j}^{-}$两个距离指标所反映评价对象的稳定状态, $C_{j}$ 值 越大，表明评价对象越接近理想解，即交通服务功能优势度 $Z(y)$ 或旅游强度 $T(x)$ 越高。

鉴于交通系统与旅游发展是相互促进、彼此依存的两大系统，任何一方滞后均将阻 碍另一方优化成长，即在典型旅游地需考虑到旅游活动开展与综合交通服务功能的协调 性, 本研究引人变异系数 $K$, 反映两大系统中各综合评价值的离散程度, 对贴近度进行 修正后为 $C_{i}^{\prime}{ }^{[33]}$ 。

$$
K=\frac{\sqrt{\sum_{j=1}^{2} I_{i j}-\bar{I} / 2}}{\bar{I}}(i=1,2, \cdots, m ; j=1,2) ; \bar{I}=\frac{1}{2} \sum_{j=1}^{2} I_{i j}
$$

修正后的贴近度为：

$$
C_{i}^{\prime}=C_{i}(1-K)
$$

式中： $I_{i j}$ 表示第 $i$ 个评价单元的第 $j$ 个评价指数。

\subsection{2 耦合协调模型}

耦合度是对两个要素或系统相互作用程度大小的衡量，需借助耦合协调度模型揭示 系统之间是否处于协调共生状态 ${ }^{[22]}$ 。显然，综合交通服务功能与旅游强度存在协同关 系：前者对区域旅游经济增长、旅游资源开发、旅游形象提升和旅游空间结构演化均产 生着驱动效应; 后者对交通运输质量、交通经济、交通网络布局和交通就业等均发挥着 反馈效应。根据改进的 TOPSIS 模型测算综合交通服务功能与旅游强度评价值，来探析两 大系统发展质量, 即 $T(x)=C_{i}^{\prime}$ 或 $Z(y)=C_{i}^{\prime}$, 构建的交通服务功能与旅游强度耦合协调模型 见参考文献 [22]。

其中，协调度 $D$ 取值在 $[0,1]$ 内，参考以往文献 ${ }^{[27,34]}$ ，分别以 $0.2 、 0.4 、 0.6 、 0.8$ 为 界，将其由高至低依次划分为：良好协调 $(0.8 \sim 1.0]$ 、中级协调 $(0.6 \sim 0.8$ ] 初级协调 (0.4 0.6]、濒临失调 (0.2 0.4]和中度失调 (0.0 0.2]。

\subsubsection{Tobit模型}

为科学定量揭示云南省综合交通服务功能与旅游强度整体关系, 明确公路交通、铁 路交通、航空运输各自与旅游强度间的数理关系，由于旅游强度取值 $[0,1]$, 因此，采用 Tobit模型来验证综合交通服务功能及不同交通服务功能模式与旅游强度的关系。具体模 型如下 ${ }^{[19]}$ :

$$
\begin{aligned}
& Y_{i t}^{*}=\beta_{0}+\beta_{1} \times Z(y)_{i t}+\beta_{2} \times X_{i t}+\mu_{i t} \\
& Y_{i t}=\left\{\begin{array}{l}
1 ; \text { if }\left(y_{i t}^{*}>1\right) \\
Y_{i t}^{*} ; \text { if }\left(0<y_{i t}^{*} \leqslant 1\right) \\
0 ; \text { if }\left(y_{i t}^{*} \leqslant 0\right)
\end{array}\right.
\end{aligned}
$$


式中: $i$ 和 $t$ 分表表示第 $i$ 个单元和第 $t$ 年; $Y_{i t}$ 表征旅游强度 ; $Y_{i t}^{*}$ 为相应隐藏变量 ; 随机误 差项 $\mu_{i t} \sim N(0, \sigma)$; $X_{i t}$ 为其他控制变量。为保证参数估计结果无偏且一致，本文采用极大似 然估计法 (MLE)，并通过 STATA 软件实现模型拟合和参数估计。

\section{3 指标体系构建}

\subsection{1 综合交通服务功能概念模型}

依据金风君等 ${ }^{[35]}$ 、王成新等 ${ }^{[36]}$ 、刘安乐等 ${ }^{[29]}$ 的研究观点，交通优势度主要涉及 “路网密 度、可达性和区位优势度” 三个维度。本文借鉴以上研究基础，首先，弥补以往缺乏对 航空网络数据分析的不足。实际上, 对处于边疆山区旅游地云南省而言, 航空网络对其 旅游可达性提升、旅游资源开发及旅游空间结构优化效应不容忽视; 其次, 以往研究忽略 了交通网络站点、换乘便捷度、旅游主客体供需关系等对交通服务功能测度带来的影响。

本文将航空网络指标及多维度交通数据纳人研究，着重分析综合交通服务功能、公 路交通、铁路交通和航空运输对云南省旅游业的贡献效应，并认为综合交通服务功能 (Comprehensive Transportation Service Function) 由 “路网密度、通行范围、通行规模、换 乘便捷度、通行效率（能力）和供需关系” 6项指标层构成（图 2)。其中，（1）路网密 度表征本区域交通运输覆盖腹地广度和规模; 通过交通支撑效应扩大服务本地的腹地范 围。（2）通行范围是衡量本区域与外界联通通畅能力，表征该种交通运输方式对本地服务 所覆盖不同等级的外区域空间腹地范围。（3）通行规模表征单位面积不同等级的交通运输 方式所承载或通行的客运量强度或此交通方式承载游客进出场站的规模强度，通过胁迫效 应倒逼旅游地交通组合形态及紧凑度优化。（4）换乘便捷度是衡量交通运输功能强弱的重 要指标, 不同交通方式的空间组合形态及衔接紧密程度, 能影响到游客旅游 “行游比” 和 游客对旅游地的感知形象。可通过科技进 步、管理方式改进等区域响应提升旅游要 素流通行效率和能级。（5）通行效率表征某 种交通运输方式以最小的通行里程承载或 中转最大客运量的强度。通过运输结构组 合优化、智慧化建设等维持旅游地交通供 给与客流需求的均衡关系。（6）供需关系反 映不同交通运输方式与旅游地居民及游客 等旅游主客体间的相互耦合依赖关系，表 征交通系统在旅游供给侧满足本地居民或 游客出行需求侧的支撑强度, 侧面反映出 居民及游客等旅游主体对旅游交通供给客 体的满意度, 主客体供需关系此消彼长对 旅游地交通网络建设产生反馈效应（表1）。

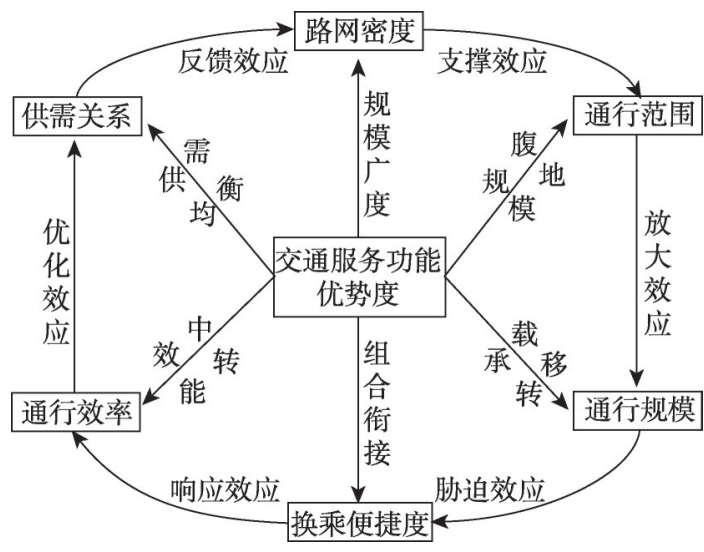

图 2 综合交通服务功能概念模型

Fig. 2 Conceptual model of comprehensive transportation service function

\section{3 .2 旅游强度概念模型}

以往关于旅游绩效评价大都基于 “人境接待过夜游客、国内过夜游客、旅游业总收 人、旅游创汇、星级饭店数、旅游景区数、旅行社数量、旅游交通密度和第三产业从业 人数” 等经济视角考量 ${ }^{[37-40]}$, 很少涉及旅游发展对当地利益相关者产生的社会效应。现实 中，区域旅游发展对当地社会、就业等方面均会产生较大影响。在参考以上研究基础 上，结合谢彦君 ${ }^{[41]}$ 旅游效应的内涵与特征，基于旅游活动 “供给一需求” 维度，构建由 


\section{表 1 综合交通服务功能评价指标体系}

Table 1 Evaluation index system of comprehensive transportation service function

\begin{tabular}{lll}
\hline 目标层 & 准则层 & 指标层 \\
\hline 综合 & 公路 & 路网密度 $/(\mathrm{km} / \mathrm{km}$ \\
交通 & 交通 & \\
服务 & 服务 & \\
功能 & 功能 & 通行范围 $/$ 分 \\
$I Z(y)$ & $\mid f_{\text {highway }}$ &
\end{tabular}

通行规模/分 通句中等城市及其以下城市规模赋权 0.3

\section{通行规模/分}

换乘便捷度/分

铁路

交通

服务

功能

$\mid f_{\text {railway }}$

通行范围/分

通行规模/分

换乘便捷度/分

通行效率/分

供需关系/分

航空 通行范围/分

通行效率

/(人次 $/ \mathrm{km})$
供需关系/分

路网密度 $/\left(\mathrm{km} / \mathrm{km}^{2}\right)$

\section{道的权重，本文分别计为 $0.5 、 0.3$ 和 0.1}

依据不同等级铁路赋权累加测算。路网密度 $D=w_{i} \times\left(L_{i} / A_{i}\right)$, 其中, $L_{i}$ 为不 同等级铁路通车里程 $(\mathrm{km}) ; A_{i}$ 为区域国土面积 $\left(\mathrm{km}^{2}\right) ; w_{i}$ 分别为高铁 (动车)、普铁权重, 分别赋权为 0.5 和 0.3

依据高铁 (动车)、普铁覆盖的城市规模等级及数量综合测算。通行范围 $F=\sum\left(w_{i} \times n_{i}\right)$, 其中, $w_{i} 、 n_{i}$ 分别为高铁（动车）或普铁通向 $i$ 类城市的权 重和数量。结合国务院印发《关于调整城市规模划分标准的通知》, 本文 将高铁 (动车) 通向特大城市、超大城市的赋权为 1 ; 通向国内I型大城 市、II型大城市赋权 0.7 ; 通向中等城市及其以下城市规模赋权 0.3 。将普 铁（ $G$ 和 $D$ 字头以外）通向特大城市、超大城市赋权 0.5 ; 通向国内I型大 城市、II型大城市赋权 0.3 ; 通向中等城市及其以下城市规模赋权 0.1 结合不同等级铁路赋权和旅客周转量测算。即：通行规模 $T=w_{i} \times \ln \left(z_{i}\right)$, 其 中, $w_{i}$ 为不同等级铁路权重; $z_{i}$ 为旅客周转量 (人次) ; 本文设定高铁 (动 车)、普铁权重分别为 0.5 和 0.3

区内各铁路站点通往最近高速路口或客运站、民用机场的平均通勤时间。 公路时速设计标准同上，若平均通勤时间 $t<60 \mathrm{~min}$ 赋 2 分; $60 \mathrm{~min} \leqslant t<120$ $\min$ 赋 1.5 分; $120 \min \leqslant t<180 \min$ 赋 0.5 分; $180 \min \leqslant t$ 赋 0 分

依据不同等级铁路赋权、客运量及通车里程综合测算。通行效率 $E=w_{i} \times \ln$ $\left(k_{i} / l_{i}\right)$, 其中, $k_{i}$ 为 $i$ 类铁路客运量 (人次); $l_{i}$ 为高铁 (动车) 或普铁通车里 程 $(\mathrm{km}) ; w_{i}$ 为高铁 (动车) 或普铁权重, 本文分别赋权为 0.5 和 0.3 依据不同等级铁路综合加权测算。供需关系 $X=w_{i} \times \sum\left[\left(s_{i} \times n_{i}\right) / p_{i}\right]$, 其 中, $s_{i}$ 为 $i$ 区域铁路站点数量 (个); $n_{i}$ 为年停靠列车趟数 (趟); $p_{i}$ 为年末 常住人口数量 (万人); $w_{i}$ 分别为高铁 (动车)、普铁的权重, 本文分别赋 权为 0.5 和 0.3

依据民航航线通向的城市规模等级及数量综合测算。通行范围 $F=$ $\sum\left(w_{i} \times n_{i}\right)$, 其中, $w_{i} 、 n_{i}$ 分别为 $i$ 地区通向不同等级规模城市的权重和数 量。本文设定将民航通向国外首都城市、国内特大城市、超大城市赋权 1 ; 通向国内 I 型大城市、II型大城市赋权 0.7 ; 通向中等及其以下城市规模 赋权 0.3 


\begin{tabular}{|c|c|c|c|}
\hline 目标层 & 准则层 & 指标层 & 指标释义 \\
\hline \multirow{8}{*}{$\begin{array}{l}\text { 综合 } \\
\text { 交通 } \\
\text { 服务 } \\
\text { 功能 } \\
I Z(y)\end{array}$} & 航空 & \multirow[t]{3}{*}{ 通行规模/分 } & 结合民航机场客货吞吐量和机场等级测算。即：通行规模 $T=d \times \ln$ \\
\hline & 运输 & & $\left(\sqrt{t_{l}+t_{h}}\right)$, 其中, $t_{1}$ 为旅客吞吐量 (万人次) ; $t_{h}$ 为货物吞吐量 $($ 万 $\mathrm{t}) ; d$ 为 \\
\hline & 服务 & & 机场等级, 不同等级机场赋权同上 \\
\hline & 功能 & \multirow[t]{2}{*}{ 航班载运率/\% } & 飞机载运率是指飞机执行航班飞行任务时实际业务载量与可提供的最大业 \\
\hline & $\mid f_{\text {aviation }}$ & & $\begin{array}{l}\text { 载 (商载) 之比, 用以反映航班运力的利用程度。航班载运率=(总周转 } \\
\text { 量/最大周转量) } \times 100 \%\end{array}$ \\
\hline & & 换乘便捷度/分 & $\begin{array}{l}\text { 区内各民用机场通往最近铁路站点、高速路口或客运站平均通勤时间。公 } \\
\text { 路时速设计标准同上, 若平均通勤时间 } t<1 \mathrm{~h} \text { 赋 } 2 ; 1 \mathrm{~h} \leqslant t<2 \mathrm{~h} \text { 赋 } 1.5 ; 2 \mathrm{~h} \leqslant \\
t<3 \mathrm{~h} \text { 赋 } 0.5 ; 3 \mathrm{~h} \leqslant t \text { 赋 } 0\end{array}$ \\
\hline & & 通行能力/分 & $\begin{array}{l}\text { 依据不同飞行区等级赋权、旅客吞吐量和飞机起降架次综合测算。即通行 } \\
\text { 能力 } C=w_{i} \times\left(T_{i} / l_{i}\right) \text {, 其中, } T_{i} \text { 为机场旅客吞吐量 (万人次 } ; l_{i} \text { 为飞机起降架 } \\
\text { 次 (万架次 } ; w_{i} \text { 为不同飞行区等级机场权重, 不同等级机场赋权同上 }\end{array}$ \\
\hline & & 供需关系/分 & $\begin{array}{l}\text { 依据不同飞行区等级赋权综合测算。供需关系 } X=w_{i} \times \sum\left(l_{i} / p_{i}\right) \text {, 其中, } l_{i} \\
\text { 为 } i \text { 等级机场飞机起降架次 (万架次); } p_{i} \text { 为年末常住人口数量 (万人); } \\
\text { 依据航空民航标准-MH5001-2000 《民用机场飞行区技术标准》, 本文将 } \\
4 \mathrm{~F} 、 4 \mathrm{E} 、 4 \mathrm{D} 、 4 \mathrm{C} \text { 级分别赋权 } 1 、 0.8 、 0.6 \text { 和 } 0.4\end{array}$ \\
\hline
\end{tabular}

“旅游产业要素供给、旅游规模、旅游消费、旅游效益和旅游效应” 5 准则层共 15 项指标 组成的旅游强度（Tourism Intensity）评价概念模型，即 “产业要素供给 一客流规模集聚 一消费过程一效益产生 一效应释放”, 强调 “要素供给” 和 “客流需求” 的共时性、历时 性过程，对旅游地旅游绩效衡量具有高度概括性（图3)。具体评价指标体系见表2。

\section{4 研究区概况}

云南省处于中国西南边陲，北接四川省，东邻贵州省和广西壮族自治区，西北为西 藏自治区，南面和西面与越南、老挝、缅甸三国接壤，具有 “东连黔桂通沿海，北经川 渝进中原，南下越老达泰柬，西接缅甸连印巴” 的地理区位优势（图 4)。国土面积 39.4 万 $\mathrm{km}^{2}$, 总人口 4830 万人 (2018 年底), 下辖 8 个地级市和 8 个自治州; 属中国经济欠发 达地区，经济综合竞争力处于全国下游水平。云南大体属亚热带高原季风气候，地貌以 类型繁多、结构复杂著称, 大致以 “云岭东侧一元江谷地”一线为界, 以东为云南高 原，西部是横断山地。其独特的区位特征、地理环境和地貌类型孕育了得天独厚的旅游

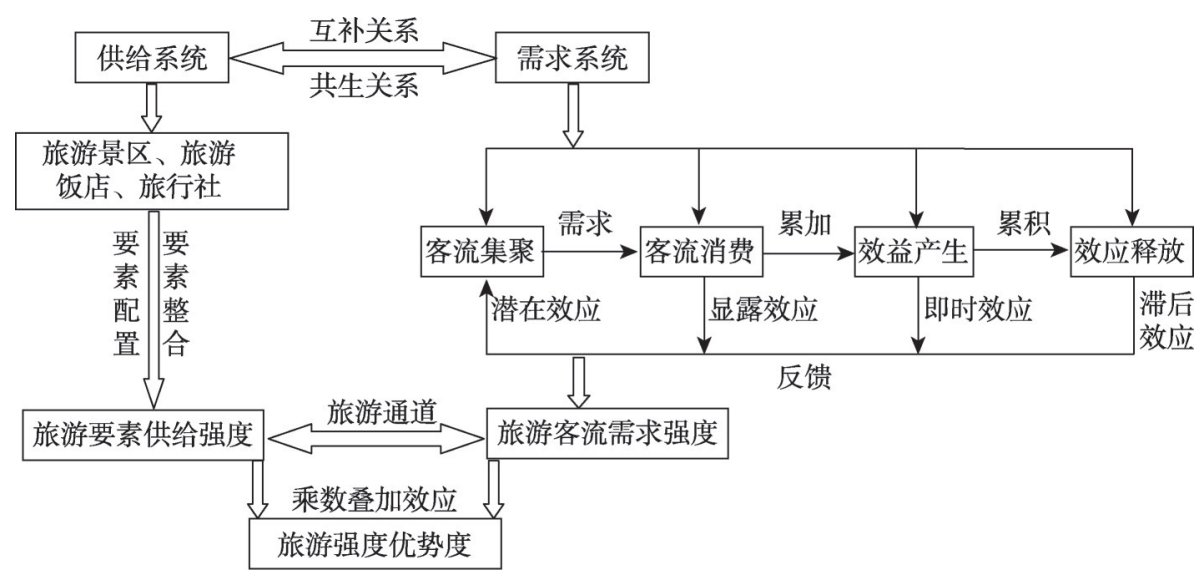

图 3 旅游强度评价概念模型

Fig. 3 Conceptual model of tourism intensity assessment 
表 2 旅游强度评价指标体系

Table 2 Evaluation index system of tourism intensity

\begin{tabular}{|c|c|c|}
\hline 目标层 & 准则层 & 指标层 (单位) \\
\hline $\begin{array}{l}\text { 旅游强 } \\
\text { 度 } / T(x)\end{array}$ & 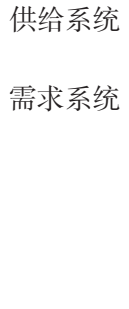 & 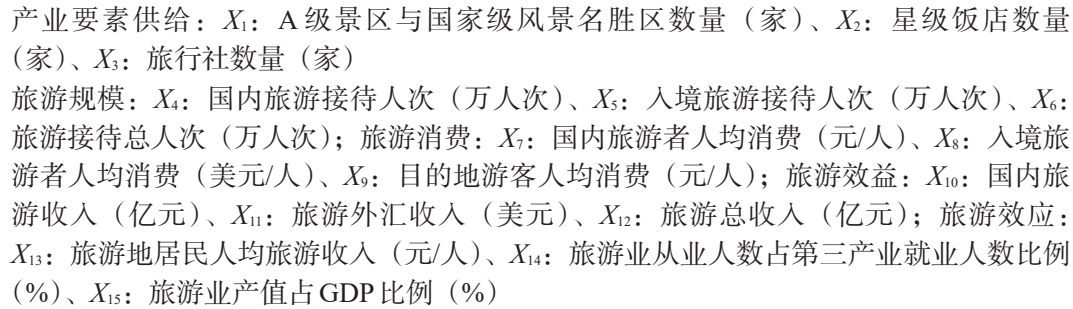 \\
\hline
\end{tabular}

资源（2019年 10 月 A 级景区达 244 家），旅游环境优良、资源种类和旅游空间结构在西南 边疆山区具有较强代表性，依托于鲜明的自然景观和独具魅力的人文风情，一直是国内 外游客旅游的热点旅游目的地。但其相对封闭的地形一定程度上制约了交通空间展布与 延伸, 也决定了边疆山区旅游发展对交通网络优化响应更加强烈。因此, 选择边疆山区 云南省为研究案例, 基于多源数据背景揭示交通演化与旅游强度的空间关系, 具有区域 典型性和实证价值。截至 2018 年底, 云南省交通闭塞状况得到初步改善, 全省公路通车 里程达 25.29 万 $\mathrm{km}$, 高速公路州市通车率达 $87.50 \%$; 铁路网密度仅为 $97.66 \mathrm{~km} /$ 万 $\mathrm{km}^{2}$, 低于全国平均水平和周边省份; 航空方面, 有 14 个民航机场通航运营, 初步形成较发达 的立体式航空运输网络体系。

\section{5 数据来源与处理}

本研究基于多源数据为分析样本，其中，交通类数据源自：高德交通大数据、12306 铁道部火车票官网 (https://kyfw.12306.cn/otn/resources/login.html)、《云南交通地图册》 《云南省交通统计资料汇编》和《云南省统计年鉴》(2007-2017年); 旅游及其他类数 据源自电子地图 POI数据、《世界银行》《云南省统计年鉴》（2007-2017年）和《云南省 商务年鉴》(2007-2017年)。数据处理: 旅游类、GDP 等价格型数据以 2006 年 GDP 平减指数为基期进行不变价处理; 交通类 数据主要借助 ArcGIS 空间分析技术对交通 道路数据进行采样、地理匹配、图层叠加 和矢量化操作。

\section{2 结果分析}

\section{1 综合交通服务功能与旅游强度协调时序 演化分析}

结合云南交通与旅游发展实际，为便 于研究, 选择2006年、2011 年和 2016年三 个时间节点探究综合交通服务功能与旅游 强度协调指数时间与空间演变特征。为验 证综合交通服务功能及旅游强度指标体系 构建是否科学合理, 运用SPSS 软件对指标

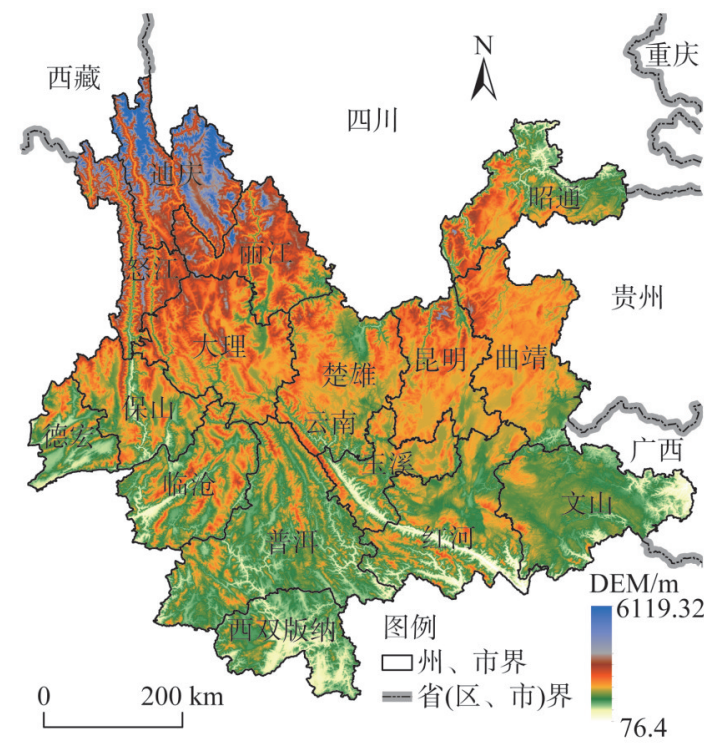

图 4 云南省区位图

Fig. 4 Location of Yunnan province 
矩阵进行 “分析 $\rightarrow$ 度量 $\rightarrow$ 可靠性分析”, 结果显示, 量表矩阵具有很高内在一致性, 可靠 性较强。通过改进 TOPSIS 和耦合协调模型测算交通服务功能 $Z(y)$ 与旅游强度 $T(x)$ 各自贴 近度及两者协调指数 $D($ 表 3$)$ 。

由云南省综合交通服务功能与旅游强度协调度变异系数可知（表3), 变异系数由 2006 年的 0.4149 降至 2016 年的 0.3692 , 表明研究期间综合交通服务功能与旅游强度协调 层级差距逐渐缩小，整体协调水平有所提升。由综合交通服务功能与旅游强度协调指数 累计百分比统计（图 5）可知：（1）2006年，主导类型为濒临失调型。中级协调（0.6 0.8 ) 占比为 $6.25 \%$; 初级协调 $(0.4 \sim 0.6)$ 占比为 $25 \%$; 濒临失调 (0.2 0.4) 占比为 $50 \%$; 中度失调（0 0.2）占比为 $18.75 \%$; 尚未出现良好协调。（2）2006-2011 年，主导 类型升级为初级协调。良好协调 $(0.8 \sim 1.0)$ 占比为 $6.25 \%$; 初级协调 $(0.4 \sim 0.6)$ 占比 $56.25 \%$; 濒临失调（0.2 0.4）占比 $25 \%$; 中度失调（0 0.2）占比 $12.5 \%$; 未出现中级协 调型。（3）2011-2016年，主导类型仍为初级失调型，但该协调层级占比提升了 6.25 个 百分点。良好协调 $(0.8 \sim 1.0)$ 占比为 $6.25 \%$; 中级协调 $(0.6 \sim 0.8)$ 占比 $6.25 \%$; 初级协调 （0.4 0.6）占比 62.5\% ; 濒临失调（0.2 0.4）占比 $18.75 \%$; 中度失调（0 0.2）州市占比 $6.25 \%$ ，表明云南综合交通服务功能与旅游强度耦合效应得到提升。进一步观察表 3 可 知， 2016 年中级协调及其以上层级占比仅有 $12.5 \%$ ，而初级协调及其以下层级占比却高 达 $87.5 \%$ ，且协调指数最好的昆明市是最差的怒江州的 6.65 倍，表明省域内部协调层级 “两极分化” 现象严重。此外，协调指数分布呈现明显 “空间锁定” 效应，高值主要指向

\section{表 3 云南省综合交通服务功能与旅游强度贴近度及耦合协调指数}

Table 3 Comprehensive score and coupling coordination degree of comprehensive transportation service function and tourism intensity in Yunnan province

\begin{tabular}{|c|c|c|c|c|c|c|c|c|c|}
\hline \multirow{2}{*}{ 州市 } & \multicolumn{3}{|c|}{ 2006年 } & \multicolumn{3}{|c|}{ 2011年 } & \multicolumn{3}{|c|}{ 2016年 } \\
\hline & $T(x)$ & $Z(y)$ & $D$ & $T(x)$ & $Z(y)$ & $D$ & $T(x)$ & $Z(y)$ & $D$ \\
\hline 昆明 & 0.5744 & 0.4119 & 0.6926 & 0.6743 & 0.8072 & 0.8572 & 0.7328 & 0.9255 & 0.9044 \\
\hline 曲靖 & 0.0897 & 0.3931 & 0.3823 & 0.1473 & 0.4539 & 0.4716 & 0.1392 & 0.4757 & 0.4641 \\
\hline 玉溪 & 0.0894 & 0.3543 & 0.3780 & 0.1044 & 0.4053 & 0.4075 & 0.1524 & 0.4743 & 0.4802 \\
\hline 保山 & 0.1201 & 0.2194 & 0.3939 & 0.1186 & 0.2861 & 0.4095 & 0.1814 & 0.3024 & 0.4762 \\
\hline 昭通 & 0.0142 & 0.1897 & 0.1629 & 0.0349 & 0.2105 & 0.2447 & 0.0576 & 0.2789 & 0.3091 \\
\hline 丽江 & 0.5017 & 0.1096 & 0.4242 & 0.6140 & 0.1578 & 0.5011 & 0.7029 & 0.1917 & 0.5489 \\
\hline 普洱 & 0.0490 & 0.2121 & 0.2821 & 0.0738 & 0.2485 & 0.3373 & 0.1766 & 0.3090 & 0.4741 \\
\hline 临沧 & 0.0637 & 0.1435 & 0.2971 & 0.1173 & 0.1935 & 0.3821 & 0.1621 & 0.2391 & 0.4395 \\
\hline 楚雄 & 0.0406 & 0.1654 & 0.2555 & 0.0650 & 0.2186 & 0.3165 & 0.1067 & 0.2585 & 0.3887 \\
\hline 红河 & 0.1476 & 0.3301 & 0.4516 & 0.2691 & 0.3431 & 0.5492 & 0.2725 & 0.4221 & 0.5755 \\
\hline 文山 & 0.2464 & 0.1386 & 0.4212 & 0.2242 & 0.2440 & 0.4834 & 0.2082 & 0.2730 & 0.4860 \\
\hline 西双版纳 & 0.2342 & 0.0845 & 0.3524 & 0.3987 & 0.1248 & 0.4360 & 0.5786 & 0.1845 & 0.5289 \\
\hline 大理 & 0.3059 & 0.2877 & 0.5445 & 0.3587 & 0.3591 & 0.5991 & 0.5365 & 0.3599 & 0.6563 \\
\hline 德宏 & 0.3231 & 0.0919 & 0.3784 & 0.3787 & 0.1052 & 0.4057 & 0.4673 & 0.1525 & 0.4795 \\
\hline 怒江 & 0.0834 & 0.0066 & 0.1111 & 0.1180 & 0.0061 & 0.1081 & 0.1884 & 0.0097 & 0.1360 \\
\hline 迪庆 & 0.5042 & 0.0126 & 0.1567 & 0.5186 & 0.0216 & 0.2039 & 0.4504 & 0.0236 & 0.2117 \\
\hline 均值 & 0.2117 & 0.1969 & 0.3553 & 0.2635 & 0.2616 & 0.4195 & 0.3196 & 0.3050 & 0.4724 \\
\hline 变异系数 & 0.8621 & 0.6490 & 0.4149 & 0.7771 & 0.7376 & 0.4118 & 0.6956 & 0.7005 & 0.3692 \\
\hline
\end{tabular}




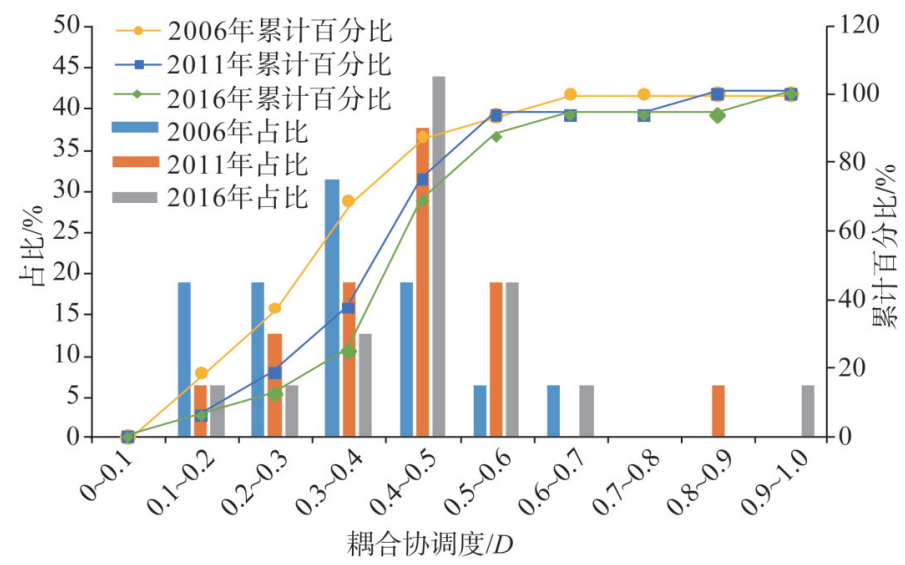

图 5 2006-2016年综合交通服务功能与旅游强度协调指数累计百分比统计

Fig. 5 Cumulative percentage statistics of coordination degree between comprehensive transportation service function and tourism intensity from 2006 to 2016

于交通区位优势明显、交通组合类型多样、旅游资源本底优越和旅游发展较为成熟的滇 中地区; 协调指数低值大都位于省域外缘地带, 远离主要交通干线或枢纽, 受到核心城 市辐射及扩散效应随地理距离增加而减弱。

综上，2006-2016年，良好协调型占比增长 6.25\%，中级协调型占比仍保持为 $6.25 \%$ ， 初级协调型占比增长 $37.5 \%$, 濒临失调型占比减少 $31.25 \%$, 中度失调型占比减低 $12.5 \%$, 且协调指数均值由 2006 年的 0.3553 上升至 2016 年的 0.4724 ; 高层级协调分布从无到有, 累计百分比曲线随年份增长逐渐向右推移，减少的低等级协调州市均由 “中度失调、濒 临失调” 跃迁升级为 “初级协调和中级协调”，综合交通服务功能与旅游强度耦合协调的 主导类型由 “濒临失调型” 升级为 “初级协调型”, 这主要得益于《云南省 “十二五” 综 合交通运输体系规划》和旅游交通扶贫政策的引导效应。此外，“十一五” 和 “十二五” 时期云南省分别作出旅游 “二次创业” 和 “旅游强省” 等重大战略决策，智慧旅游与数 字交通建设成效明显，优化与加速旅游产业与交通要素配置效率，促使综合交通服务功 能与旅游发展耦合效应不断增强。

\section{2 综合交通服务功能与旅游强度协调空间分异特征}

\subsection{1 总体格局}

为探究综合交通服务功能与旅游强度协调总体空间分异特征，运用 ArcGIS 空间分析 对 2006 年、2011 年和 2016 年三个节点协调等级进行空间可视化（图 6)。结合协调指数 空间分异图（图6），运用趋势面分析方法对 2006年、2011 年和2016年云南综合交通服 务功能与旅游强度协调指数进行趋势分析（图 7)。总体上，2006-2016年协调指数表现 为 “中部高，东西部和南北两翼低” 的空间布局态势，且趋势线在东西方向上变化较为 陡峭，南北方向上变化相对平稳，说明协调指数在东西方向上空间分异较为剧烈，南北 方向上空间异质性相对较小。

具体而言：东西方向上，2006年、2011年和 2016年协调指数趋势线均呈 “倒 U” 型，说明研究期间协调指数表现为 “中间高，东西两翼低” 空间态势，随着时间演化， “倒 U” 型弧度增大，表明中部与东西两翼协调指数空间分异程度趋于加剧。但研究期间 东部协调指数始终高于西部，究其原因在于东部经济相对发达，居民消费水平高，加之 


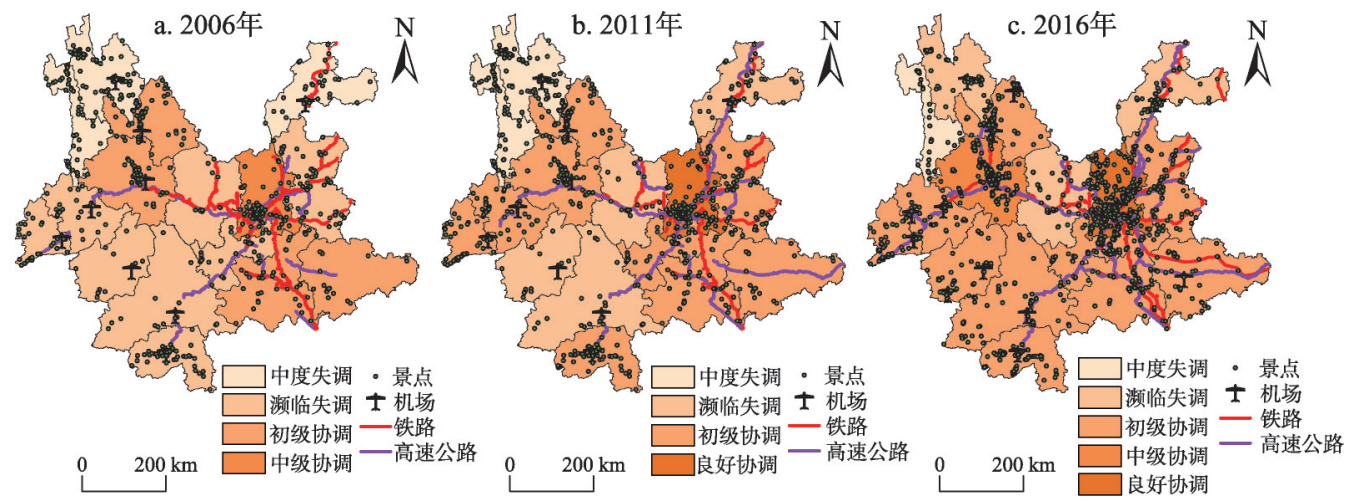

图 6 综合交通服务功能与旅游强度协调格局

Fig. 6 Coordination pattern of comprehensive transportation service function and tourism intensity
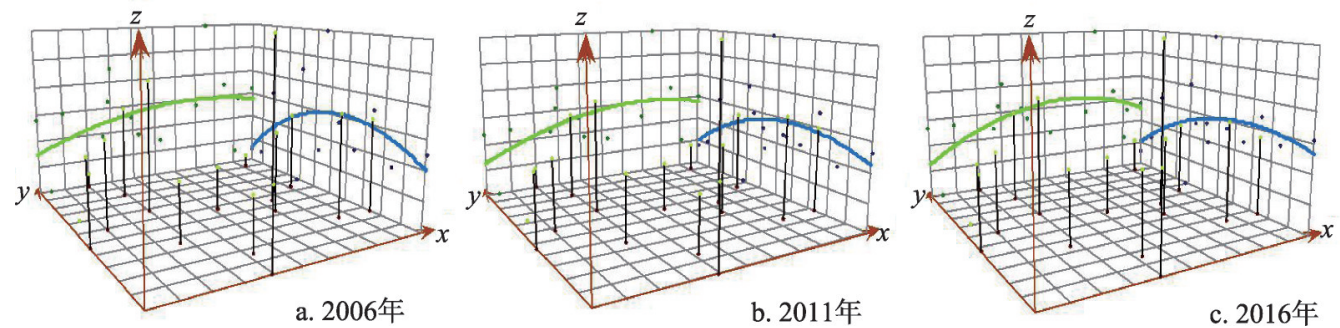

图 7 综合交通服务功能与旅游强度协调指数趋势面

Fig. 7 Trend of comprehensive transportation service function and tourism intensity coordination index

地形相对平坦，利于交通网络形态优化、可达性提升和旅游资源规模性、集群式开发， 综合交通服务功能对旅游强度驱动效应表现强势; 而滇西地区大都是国家扶贫开发的重 点片区，受制于自然地理因素、经济实力、资源开发强度和区域不平衡发展政策综合牵 制，综合交通服务功能与旅游强度关系呈现强烈 “掣肘效应”。南北方向上，2006-2016 年协调指数趋势线均呈现 “倒 U” 型，表明研究期间协调指数呈现 “中间高，南北两翼 低” 布局态势。随着时间变化, “倒U” 型弧度开始趋向平稳, 说明中部与南北两翼协调 指数分异程度趋于减缓，但研究期间南部协调指数始终高于北部。

综上，云南综合交通服务功能与旅游强度协调指数表现为明显空间指向性特征，省 域中部为协调指数高值区, 受距离衰减规律影响, 由滇中城市圈依次向东西两侧和南北 两翼等边缘地带随地理距离增加而衰减，协调指数趋势线呈以昆明为中心的同心环带状 分布，“核心一边缘”空间结构显著，这与云南交通骨架网、“轴辐式网络化”旅游空间 结构和以昆明为中心的经济格局相吻合; 这也符合约翰・弗里德曼（John Friedmann）的 核心边缘理论，其主要机理可能是在循环累积因果机制和 “规模报酬” 效应下，协调指 数在空间选择上易形成 “路径依赖” 和 “空间锁定”。

\subsection{2 区域差异特征}

在区域差异方面，由图 8 可知，研究期间云南省六大地理旅游片区综合交通服务功 能与旅游强度协调指数均保持连续上升势头，且区域差异特征明显，呈 “滇中（昆 明、曲靖、楚雄、玉溪）>滇东南（红河、文山）>滇西南（西双版纳、普洱）> 滇 西（保山、德宏、临沧）> 滇西北（丽江、大理、迪庆、怒江）> 滇东北（昭通）” 
的俱乐部空间态势。相比较而 言, 2016年, 滇中旅游圈的优 势在于地势相对平坦, 交通组 合类型丰富（机场、高铁、高 速公路）、铁路站点覆盖率高 (100\%)、高速公路密度也相对 较高 $\left(0.0186 \mathrm{~km} / \mathrm{km}^{2}\right)$, 旅游 资源禀赋优势明显（A 级景区 占全省的 $30.33 \%$ ), 旅游要素 供给充裕（星级旅行社和星级 饭店分别占全省的 $42.45 \%$ 和 $27.25 \%$ ）。交通网络设施将区 域各级旅游增长极及其周边地 带有机结合, 强化了交通网络

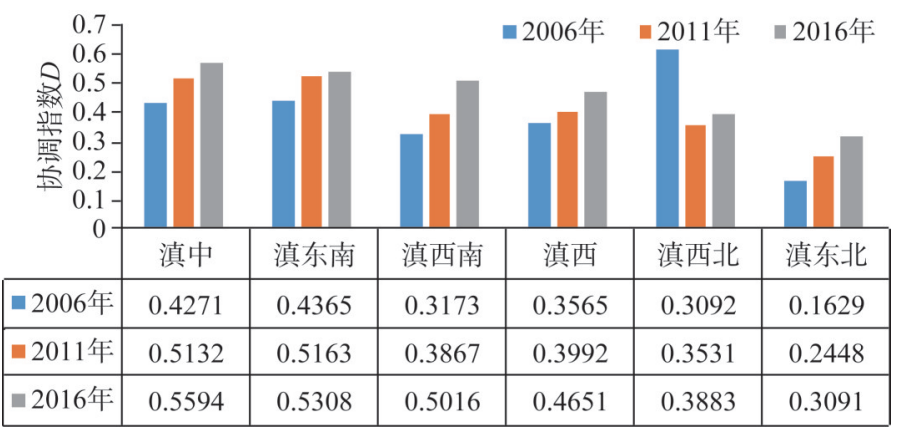

注：六大地理旅游片划分依据《云南省旅游产业“十三五”发展 规划》。

图 8 云南省六大地理旅游片区综合交通服务功能与 旅游强度协调指数对比

Fig. 8 Comparison of comprehensive transportation service function and tourism intensity coordination index of six geographical tourism areas in Yunnan province

节点、轴线对旅游绩效的作用强度，也为旅游客流的空间扩散提供便捷通道载体，放大 了区域旅游经济的规模效应与扩散效应, 使得各级旅游中心地系统资源要素利用效率达 到最佳生产前沿面, 最终形成以核心城市为内生增长极, 以交通网络为轴线连接的区域 旅游圈或旅游目的地群落。滇东南邻近滇中旅游圈, 交通设施的空间溢出效应和联动效 应显著, 且旅游资源相对丰富, 协调指数也相对较高。此外, 协调指数洼地主要位于滇 西北和滇东北旅游区，这些地区的共性特征为处于省域交通网络神经末梢，远离交通枢 纽城市，受交通核心区空间辐射效应影响随地理距离增加而衰减，网络密度较低（2016年 滇西北旅游区高速公路密度仅为 $0.0056 \mathrm{~km} / \mathrm{km}^{2}$ ) ; 交通组合类型较少 (怒江无快速交通 分布, 迪庆无铁路), 路网交叉衔接度低; 自身旅游产业要素有待整合与优化, 旅游客流 规模与消费不足, 加之复杂地形对交通网络空间展布的遏制, 旅游强度发达区标杆效应 及技术优势扩散等明显减弱。体现了人地关系系统中自然地理因素、社会经济因素对交 通与旅游共生强弱关系的综合制约。

\subsection{3 不同交通方式与旅游强度协调度空间分异}

云南省以高原山地为主, 地形相对封闭, 交通发展是其旅游经济增长的前提。为揭示 不同类型交通方式与旅游强度协调的差异特征, 以 2016 年的数据为样本, 并结合 ArcGIS 软件对公路、铁路和航空各自与旅游强度协调空间分异特征进行可视化（图9)。总体 上，不同类型交通方式与旅游强度协调度空间布局存在显著差异性。（1）公路交通方 面, 整体协调型相对较好, 以初级协调型为主 (占比为 $62.5 \%$ ), 这与云南省 “以公路为 主线，以铁路、航空为补充的交通网络” 特征相契合。中级协调型仅有昆明; 初级协调 型州市包括曲靖、玉溪、红河等 10 个州市; 濒临失调型为昭通、丽江和楚雄; 中度失调 型包括怒江和迪庆, 区位指向于省域边缘地带。(2) 铁路交通方面, 协调度高值区主要 沿铁路干线分布，集中在中东部地区，这与云南省 “东强西弱” 的铁路网络格局密切相 关。中级协调型仅有昆明; 初级协调型包括大理和红河; 濒临失调型有曲靖、楚雄、玉 溪、丽江、文山、昭通、保山 7 个州市; 其余州市为中度失调型，区位指向于 “云岭一 哀牢山一元江谷地” 西侧, 受自然地理和社会经济因素综合制约, 以上地区无铁路网络 覆盖, 铁路交通对旅游流的空间转移、旅游资源开发的联动效应受到遏制。(3) 航空运 


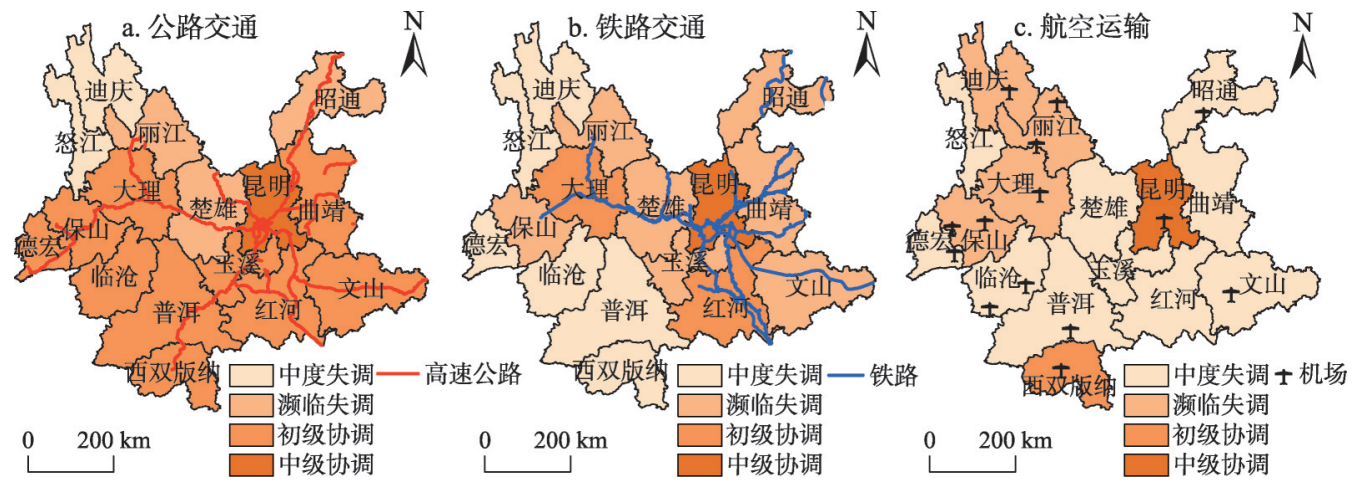

图 9 不同交通类型与旅游强度协调空间分异

Fig. 9 Spatial differentiation of coordination between different modes of transportation and tourism intensity

输方面, 协调度优势区主要集中于省域中部、西部和南部部分州市, 主要归因于云南省 西部为横断山地，陆路交通空间展布较为困难，且交通建设成本高及工程实施难度大， 但西部和南部旅游资源禀赋优势明显, 受旅游发展 “胁迫效应” 驱动，机场等设施主要 布局在西部和南部旅游资源密集区, 比如西双版纳、丽江、迪庆等著名传统旅游地均主 要依靠航空运输, 航空运输对目的地旅游经济的提质增效发展功不可没。随着云南省交 通运输网络建设从原来的以公路为骨干向以航空为先导、陆路为骨架、水运为补充的交 通网络发展，航空运输对目的地旅游发展的乘数效应将进一步得到释放。

\section{3 不同交通服务功能对旅游强度的影响分析}

\subsection{1 估计模型指标的选取}

在变量选取方面，被解释变量设为：旅游强度 $[T(x)]$ ；核心自变量设为：综合交通服 务功能 $[Z(y)]$ 、公路服务功能 $\left(f_{\text {highway }}\right)$ 、铁路服务功能 $\left(f_{\text {railway }}\right)$ 和航空服务功能 $\left(f_{\text {aviation }}\right)$; 控制变量：（1）旅游地居民可支配收人（RI）。居民可支配收人能够从供需两端影响旅游产 业发展规模，选取旅游地城镇居民人均可支配收人（元）表征，由 2006 年为基年经过测算 GDP 平减指数调整后得到 ${ }^{[19,42]}$ 。(2) 旅游资源禀赋 $(T R E)$ 。旅游资源是旅游者目的地选 择的重要参考因素, 选取各研究单元 $3 \mathrm{~A}$ 级以上旅游景区 (点) 和国家风景名胜区数量, 并 依据相关标准中对应分值加总求和得到该要素值（分） ${ }^{[3,37,39]}$ 。（3）市场化程度（MD）。 旅游市场化程度是旅游经济活跃的综合体现, 市场化程度越高, 越有利于旅游强度的提 升，选取旅游业总收人占第三产业增加值的比例（\%）进行表征 ${ }^{[19,43,44]}$ 。（4）对外开放水平 $(O L)$ 。区域旅游对外开放水平有利于旅游业积极参与分享国际化带来的信息、科技、资源 等有价值的要素，选取实际利用外商直接投资额（亿美元）来表征区域对外开放度 ${ }^{[2,45]}$ 。

\subsection{2 估计模型的识别与分析}

模型识别之前，对旅游强度与交通服务功能等变量数据时间序列上的因果关系进行检 验, 发现各变量与旅游强度之间至少存在单向因果关系, 各变量对旅游强度的 Granger 原 因都至少通过了 0.10 的显著性检验。表 4 为旅游强度 $[T(x)]$ 对综合交通服务功能 $[Z(y)]$ 、

公路服务功能 $\left(f_{\text {highway }}\right)$ 、铁路服务功能 $\left(f_{\text {ralway }}\right)$ 、航空服务功能 $\left(f_{\text {aviation }}\right)$ 的回归结果。 Wald 值均在 $1 \%$ 水平上显著, 表明估算结果整体是有效的, LR 检验结果强烈拒绝原假 设，说明采用随机效应的面板 Tobit模型是合理的。

回归（1）和回归（2）为全部州市旅游强度对综合交通服务功能的回归结果。可以 看出, 综合交通服务功能的系数显著为正 (0.076), 且加人控制变量后的回归系数 
表 4 不同交通服务功能对旅游强度的影响

Table 4 The influence of different transportation service functions on tourism intensity

\begin{tabular}{lccccc}
\hline \multirow{2}{*}{ 变量 } & $T(x)$ & $T(x)$ & $T(x)$ & $T(x)$ & $T(x)$ \\
\cline { 2 - 6 } & 回归 $(1)$ & 回归 $(2)$ & 回归 $(3) f_{\text {highway }}$ & 回归 $(4) f_{\text {railway }}$ & 回归 $(5) f_{\text {aviation }}$ \\
\hline$Z(y)$ & $0.076^{* * * *}(3.62)$ & $0.046^{* * *}(3.28)$ & $0.052^{* * *}(4.56)$ & $0.039^{* * *}(2.28)$ & $0.079^{* * * *}(3.68)$ \\
$\ln R I$ & - & $0.102^{* * * *}(4.62)$ & $0.083^{* * * *}(4.69)$ & $0.095^{* * *}(2.67)$ & $0.136^{* * *}(4.69)$ \\
$\ln T R E$ & - & $0.138^{* * *}(5.94)$ & $0.068^{* * * *}(3.38)$ & $0.089^{* * *}(2.21)$ & $0.119^{* * *}(4.39)$ \\
$\ln M D$ & - & $0.062^{* * * *}(4.63)$ & $0.035^{* * * *}(3.18)$ & $0.026^{* * *}(2.56)$ & $0.097^{* * *}(2.69)$ \\
$\ln O L$ & - & $-0.097(-1.28)$ & $-0.162(-0.68)$ & $-0.086(-1.37)$ & $-0.066(0.65)$ \\
Cons & $0.502^{* * * *}(5.28)$ & $-0.208^{* * *}(-1.98)$ & $0.382^{* * *}(2.39)$ & $-0.394^{*}(-1.69)$ & $0.402^{* * *}(2.04)$ \\
$N$ & 176 & 176 & 176 & 176 & 176 \\
Wald 检验 & $196.38^{* * * *}$ & $368.19^{* * * *}$ & $269.38^{* * * *}$ & $289.64^{* * *}$ & $329.37^{* * *}$ \\
LR 检验 & $200.56^{* * * *}$ & $169.38^{* * * *}$ & $102.39^{* * * *}$ & $135.59^{* * * *}$ & $156.39^{* * * *}$ \\
\hline
\end{tabular}

注： ${ }^{* * * * * *}$ 分别表示 $10 \% 、 5 \%$ 和 $1 \%$ 的显著性水平; 括号内为 $t$ 值。

（0.046）低于未加人控制变量的（0.076），说明从整体来看，综合交通服务功能对旅游强 度存在着显著促进作用，其每提升 1 个百分点，旅游强度相应增长 $0.046 \%$ ，综合交通服 务功能与旅游强度存在较强耦合共生性。回归 (3) 回归 $(5)$ 分别为公路 $\left(f_{\text {highway }}\right)$ 、铁 路 $\left(f_{\text {railway }}\right)$ 和航空 $\left(f_{\text {aviation }}\right)$ 等不同交通服务功能对旅游强度的回归结果。具体来看, （1）三大交通服务功能系数均显著为正，且不同交通服务功能对旅游强度的贡献效应呈 现 “航空 (0.079) > 公路（0.052）> 铁路（0.039）” 的不均衡特征，表明航空运输服 务功能对旅游强度拟合关系较为理想。究其原因, 云南地质地貌条件复杂, 对陆路交通 空间拓展限制性较大，而航空运输建设几乎不受地形影响，且快速方便、轻松舒适、安 全可靠，加之云南民航机场州市通航率较高（2016年州市通航率达 $75 \%$ ），已初步形成以 昆明为中心，连接省内及周边省际的支线航空网络，辐射国内大中城市的干线网络，面向 东南亚、南亚的国际及地区航线网络的三个轮辐式为主及城市对式结构互补的航线网络 ${ }^{[4]}$; 依托于 “紧凑” 的机场区域格局，旅游产业要素流连续前向与后向的“链条式” 传递， 放大了要素的规模效应与外溢效应，机场的 “跨界” 服务价值空间效应增大。(2) 公路 交通服务功能对旅游强度的贡献效应次之, 主要归因于云南高等级公路占比较少, 比如 2016 年高速公路通车里程仅占公路通车总里程的 $1.74 \%$, 且地区间分布差异显著, 东 部、中部密度较大, 西部和南部密度小 ${ }^{[46]}$ 。未来应加快临沧、昭通等交通服务功能落后 区的交通跨区域建设，实现与邻省、邻国等重要交通枢纽城市、交通干线无缝衔接，发 挥外部优势资源要素流以 “空间外溢” 形式对本地旅游经济增长的涓滴效应。（3）铁路 交通服务功能对旅游强度贡献效应最弱, 这主要受制于云南铁路交通建设尚未真正形成 网络形态, 站点密度较低、通行规模小、场站换乘便捷性较弱, 且云南城际高铁网络尚 未形成，沪昆、南昆高铁为区外交通，仅对昆明、曲靖、红河、文山等州市有影响，全 省 $68.75 \%$ 的州市无高铁通行, 铁路站点覆盖州市数量占比较少, 与其他交通方式中转衔 接性弱, 这与上文的分析结果相呼应。未来应以特色旅游资源为导向, 积极推进干线铁 路、城际铁路、市域（郊）铁路等引人机场区域，发挥机场的 “跨界” 空间服务价值。

各控制变量对旅游强度表现出不同程度的影响。其中，旅游地居民收人（RI）回归 系数显著为正 (0.102), 说明本区域居民可支配收人的增加, 能够激发旅游者的出游动机 和支持本地旅游基础设施建设, 扩大旅游市场规模, 产生规模效应; 旅游资源禀赋 (TRE) 
回归系数显著为正 (0.138), 说明区域旅游资源禀赋优势是吸引客流集聚的核心要素, 资源差异能够引导交通站点、网络等布局，进而对客流的规模流向、流速产生引导效 应; 市场化程度 $(M D)$ 回归系数显著为正 (0.062), 说明本地旅游产业综合表现较为活 跃，旅游经济对国民经济的贡献效应较为良好; 对外开放水平 $(O L)$ 回归系数为负值 $(-0.097)$, 但不显著，说明云南省对外开放水平较低一定程度上制约了本地旅游强度提升。

综上，交通服务功能通过提升旅游地居民收人、拓展客源市场规模、旅游资源开 发、提高旅游对外开放度等，不断促使旅游地产业要素流、技术流、资金流、劳动力 流、信息流等在区域间传导与交换, 并借助目的地政府调控力、经济内生力、市场驱动 力、社会调节力等驱动力量, 以不同作用方式对目的地旅游经济提质增效发展产生联动 效应。需要注意的是, 自然地理环境因素（地形起伏度、空气质量）对目的地旅游强度 的影响也不可忽略（图 10）。

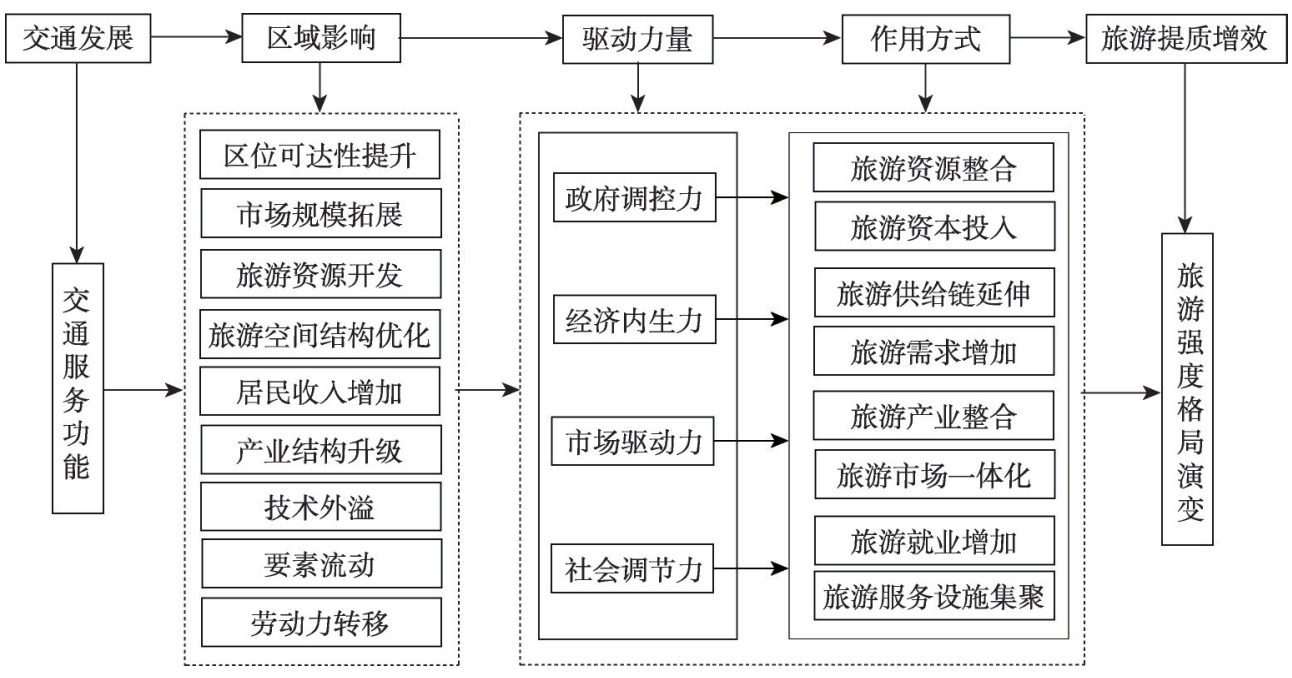

图 10 交通服务功能对旅游强度的影响机理

Fig. 10 The influence mechanism of traffic service function on tourism intensity

\section{3 结论与讨论}

\section{1 结论}

（1）2006-2016年，云南综合交通服务功能与旅游强度协同效应逐渐凸显。协调指 数均值由 0.3553 上升至 0.4724 , 高协调等级分布从无到有，累计百分比曲线随年份增长 逐渐向右推移，耦合协调的主导类型由 “濒临失调型” 升级为 “初级协调型”。

（2）研究期间，云南省综合交通服务功能与旅游强度协调度空间差异性特征显著。 具体来看, (1) 协调指数总体格局表现为明显空间指向性, 省域中部为协调指数峰值区, 受距离衰减规律影响, 由滇中城市圈依次向东西两侧和南北两翼边缘性地带随地理距离 增加而递减； (2) 区域差异呈现 “滇中 > 滇东南 > 滇西南 > 滇西 > 滇西北 > 滇东北” 的俱 乐部空间态势; 3 不同交通类型方式与旅游强度协调度空间分异特征存在显著差异性。

（3）在不同交通服务功能对旅游强度的影响分析方面，公路、铁路、航空与旅游强 度拟合优度存在差异，整体上不同交通服务功能对旅游强度的贡献效应呈现 “航空 > 公 
路 > 铁路” 的不均衡特征。各控制变量对旅游强度表现出不同程度的影响, 旅游地居民 收人、旅游资源禀赋、市场化程度均对旅游强度呈现正向促进效应，但对外开放水平回 归系数为负值, 但不显著, 说明云南省对外开放水平较低一定程度上制约了区域旅游强 度提升。

\section{2 讨论}

在当前复杂的发展环境下，从空间视角探索边疆典型山区旅游地云南省交通系统与 旅游强度耦合作用机理、协调分异特征，有利于凸显交通在边疆民族地区旅游扶贫的服 务功能与效能, 切合当前旅游发展规模与质量匹配研究不足的实际, 客观上促进交通发 展与旅游强度耦合分异规律的把握与重新审视，同时深化了对交通与旅游经济关系的认 识, 丰富了现代旅游交通的研究内容与方法体系。鉴于云南省不同交通服务功能及因素 对旅游强度的贡献效应存在差异，（1）针对 “东强西弱” 的交通服务功能格局，应强化 滇西、滇西南地区综合交通对旅游发展的支撑效应。提升其公路等级，打通铁路出境通 道，增加航线密度，并借助沿边区位和资源禀赋优势发展边（跨）境旅游，协调好综合 交通与旅游经济的关系, 缩小与东部地区的差异。(2) 针对不同交通服务功能对旅游强度 的贡献效应存在差异的现状, 应加快线路和场站建设, 实现交通运输体系的无缝衔接, 发挥子交通系统的比较优势。强化公路、铁路客运站和机场的无缝衔接, 提高旅游地综 合客运枢纽一体化水平和集散效率。（3）对外开放水平制约了本地旅游强度的提升，亟 需加快沿边地区开放开发, 坚持旅游产业发展 “引进来, 走出去” 原则, 提升对外旅游 联系度，积极参与跨区域旅游合作，引进国际化带来有价值的信息、科技和资源等要素。

需要说明的是, 以典型旅游地云南省交通服务功能与旅游发展时空关系为实证虽有 一定意义，但在以下方面仍待进一步探讨：（1）现实中，旅游绩效增长可能与周边省域 (国家) 交通系统、经济规模、居民消费能力及对外开放度等要素存在关联，尤其是随着 跨区域智慧交通等技术性变革，本地旅游强度可能会因邻近或周边地带的交通网络拓展 而增强, 交通系统桥梁与通道功能及其本身引起的空间交互作用为研究从空间效应视角 洞悉交通服务功能对旅游强度外溢效应产生的影响机制提供了新思路。此种空间作用方 式、交互强度和影响机制如何? 后续研究有必要适当引人合理的空间效应辨识方法与模 型，从空间效应视角揭示交通服务功能对旅游强度的溢出效应及动力机制。(2) Gao 等 ${ }^{[4]}$ 利用2004-2015 年中国城市面板数据评估高铁（HSR）对旅游业增长的影响，表明高铁 连接度提升减少了游客在中心城市邻近或周边地带的住宿等消费成本，不会促进旅游中 心邻近或周边地带的旅游收人增加, 但会提升周边地区旅游区位可达性, 交通改善加强 了经济两极分化。这与本文的交通能够改善旅游地区位可达性的研究结论不谋而合, 均 反映了从新经济地理学理论视角推断出的核心一边缘旅游发展预测, 提供了关于交通一 旅游关系的新证据, 补充了关于交通和旅游业增长关系的文献; 但其 “高铁交通改善加 强了经济两极分化” 的研究结论与本文认为 “交通改善可能存在要素流的外溢效应” 的 研究结论相异, 可能是研究空间单元尺度大小和时间尺度长短不一所致。区域交通网络 完善, 尤其是快速交通系统开通在短期之内为沿线旅游地带来显著的比较优势和轰动效 应, 因此能够促进当地旅游业增长, 但随着区域交通系统网络化与均衡化发展, 最初的 比较优势逐渐丧失, 旅游地之间再次进入完全竞争状态, 其对旅游业发展的贡献度也逐 渐降低，甚至可能带来负面效应。基于更大时间尺度和不同空间尺度研究交通对旅游业 的影响, 其研究结论出现差异的情况并不奇怪, 且学术界已经形成 “快速交通（高铁） 
极大加速旅游地经济增长” 和 “快速交通对旅游地经济带动作用不大” 两种相背离的观 点, 尽管这些研究结论多源于数据实证, 但仍存在数据可靠性不足、复合数据难以剥离 等的影响 ${ }^{[48]}$ 。未来研究应从完善数据收集方法、更新数据挖掘技术、合理采用旅游大数 据等途径，将微、中、宏观的空间尺度与短、中、长期的时间尺度相结合，从多元时空 视角深人探讨和交叉验证交通服务功能与旅游业发展的关系。

\section{参考文献(References):}

[1] 叶茂, 王兆峰. 武陵山区交通通达性与旅游经济联系的耦合协调分析. 经济地理, 2017, 37(11): 213-219. [YE M, WANG Z F. Analysis on the influence mechanism of transportation network for the spatial structure of regional tourism: Case of Wuling Mountain Area. Economic Geography, 2017, 37(11): 213-219.]

[2] 裴韬, 刘亚溪, 郭思慧, 等. 地理大数据挖掘的本质. 地理学报, 2019, 74(3): 586-598. [PEI T, LIU Y X, GUO S H, et al. Principle of big geodata mining. Acta Geographica Sinica, 2019, 74(3): 586-598.]

[3] FROIDH O. Perspectives for a future high-speed train in the Swedish domestic travel market. Journal of Transport Geography, 2008, 16(4): 268-277.

[4] CHRISTINE C, PRTER F. Maintaining sustainable island destinations in Scotland: The role of the transport-tourism relationship. Journal of Destination Marketing \& Management, 2014, 3(3): 162-167.

[5] GUI L, DAVID T D. Destination morphology: A new framework to understand tourism-transport issues?. Journal of Destination Marketing \& Management, 2014, 3(3): 162-172.

[6] SPENCER D M. Airport stops and flights on small airplanes as inhibitors of tourism related air travel: A case study. Tourism Management, 2009, 30(6): 838-846.

[7] SPASOJEVIC B, LOHMANN G, SCOTT N. Air transport and tourism-a systematic literature review (2000-2014). Current Issues in Tourism, 2018, 21(9): 975-997.

[8] LORENZO M, JUDIT Z. Tourists intra-destination visits and transport model: A bivariante probit model. Annals of Tourism Research, 2013, (43): 529-546.

[9] CHRISTER T. Examining tourists' long-distance transportation mode choices using a Multinomial Logit regression model. Tourism Management Perspectives, 2015, (15): 115-121.

[10] JUAN G B, MANUELA D, MANUELA P. Tourism and transport systems in mountain environments: Analysis of the economic efficiency of cableways in South Tyrol. Journal of Transport Geography, 2014, 36(4): 1-11.

[11] THIRUMALAISAMY R, SUDHEER K B. ITTS: Intelligent transport and tourism system. Procedia Computer Science, 2015, (50): 191-196.

[12] 汪德根, 牛玉, 陈田, 等. 高铁驱动下大尺度区域都市圈旅游空间结构优化: 以京沪高铁为例. 资源科学, 2015, 37 (3): 581-592. [WANG D G, NIU Y, CHEN T, et al. Optimizing tourist spatial structure for large scale regional metropolitan circles under the Beijing-Shanghai high-speed rail. Resources Science, 2015, 37(3): 581-592.]

[13] 张允翔, 周年兴, 申鹏鹏, 等. 1996-2016 年间江苏省旅游空间结构演化与影响机制研究. 长江流域资源与环境, 2018, 27(1): 107-115. [ZHANG Y X, ZHOU N X, SHEN P P, et al. Study on the evolution and influence mechanism of tourism spatial structure in Jiangsu province from 1996 to 2016. Resources and Environment in the Yangtze Basin, 2018, 27(1): 107-115.]

[14] 李一曼, 修春亮, 孔翔. 浙江陆路交通对区域旅游空间结构及发展的影响研究. 地理科学, 2018, 38(12): 2066-2073. [LI Y M, XIU C L, KONG X. Influence of land transportation network evolution on spatial structure and development of regional tourism in Zhejiang province. Scientia Geographica Sinica, 2018, 38(12): 2066-2073.]

[15] 李保超, 王朝辉, 李龙, 等. 高速铁路对区域内部旅游可达性影响: 以皖南国际文化旅游示范区为例. 经济地理, 2016, 36 (9): 182-191. [LI B C, WANG Z H, LI L, et al. The influence of high-speed railways on accessibility of tourism in the region: A case study of Southern Anhui International Cultural Tourism Destination. Economic Geography, 2016, 36(9): 182-191.]

[16] 郭建科, 王绍博, 王辉, 等. 哈大高铁对东北城市旅游供需市场的空间效应研究: 基于景点可达性的分析. 地理科学 进展, 2016, 35(4): 505-514. [GUO J K, WANG S B, WANG H, et al. Impact of Harbin-Dalian high-speed railway on the spatial distribution of tourism supply and demand markets in Northeast China cities: Based on the accessibility of the scenic spots. Progress in Geography, 2016, 35(4): 505-514.] 
[17] 陈方, 李俊芳, 戎晓峰. 高铁对区域旅游交通可达性格局的影响分析. 交通运输系统工程与信息, 2016, 16(4): 225230, 247. [CHEN F, LI J F, JI X F. The impact of high-speed railway on the spatial pattern of regional tourism transport accessibility. Journal of Transportation Systems Engineering and Information Technology, 2016, 16(4): 225-230, 247.]

[18] 王兆峰, 徐赛. 不同交通方式对旅游效率的影响与评价: 以张家界为例. 地理科学, 2018, 38(7): 1148-1155. [WANG Z F, XU S. Influence and evaluation of different traffic modes on tourism efficiency: Taking Zhangjiajie as an example. Geographic Science, 2018, 38(7): 1148-1155.]

[19] 魏丽, 卜伟, 王梓利. 高速铁路开通促进旅游产业效率提升了吗?: 基于中国省级层面的实证分析. 经济管理, 2018, (7): 72-90. [WEI L, BO W, WANG Z L. Does the high-speed railway affect the tourism industry efficiency?: Empirical evidence from Chinese provincial data. Business Management Journal, 2018, (7): 72-90.]

[20] 康晓羽. 交通网络影响下的城市旅游效率分析: 以山东省十七地市为例. 济南: 山东财经大学, 2016. [KANG X Y. Analysis of city tourism efficiency under the influence of transportation network-taking seventeen cities in Shandong province as an example. Jinan: Shandong University of Finance and Economics, 2016.]

[21] ZHENG Q X, KUANG Y Q, HUANG N S. Coordinated development between urban tourism economy and transport in the Pearl River Delta, China. Sustainability, 2016, 8(12): 1338.

[22] 郭向阳, 穆学青, 明庆忠. 云南省旅游经济与交通系统耦合空间态势分析. 经济地理, 2017, 37(9): 200-207. [GUO X Y, MU X Q, MING Q Z. Coupling space situation of tourism economy and traffic system in Yunnan. Economic Geography, 2017, 37(9): 200-207.]

[23] 余菲菲, 胡文海, 荣慧芳. 中小城市旅游经济与交通耦合协调发展研究: 以池州市为例. 地理科学, 2015, 35(9): 11161122. [YU F F, HU W H, RONG H F. Coordinated development about tourism economy and transportation in medium and small cities: Chizhou as example. Scientia Geographica Sinica, 2015, 35(9): 1116-1122.]

[24] 王兆峰, 徐赛, 邓楚雄. 高速公路对武陵山区旅游城市吸引力影响及差异. 经济地理, 2016, 36(12): 189-196. [WANG Z F, XU S, DENG C X. Influence and differences of highway on tourism cities' attraction in Wuling Mountain Area. Economic Geography, 2016, 36(12): 189-196.]

[25] 汪德根, 陈田, 陆林, 等. 区域旅游流空间结构的高铁效应及机理: 以中国京沪高铁为例. 地理学报, 2015, 70(2): 214-233. [WANG D G, CHEN T, LU L, et al. Mechanism and HSR effect of spatial structure of regional tourist flow: Case study of Beijing-Shanghai HSR in China. Acta Geographica Sinica, 2015, 70(2): 214-233.]

[26] 王莹, 刘岭, 王家康. 高速铁路网络化客流分配方法. 交通运输系统工程与信息, 2019, 19(1): 111-117. [WANG Y, LIU L, WANG J K. High-speed railway network passenger assignment. Journal of Transportation Systems Engineering and Information Technology, 2019, 19(1): 111-117.]

[27] 践晓峰, 姜莉, 陈方. 云南省县域城镇化与交通优势度的时空协同性演化分析. 地理科学, 2017, 37(12): 1875-1884. [JI X F, JIANG L, CHEN F. Spatio-temporal cooperative evolution analysis of transportation superiority and county urbanization in Yunnan province. Scientia Geographica Sinica, 2017, 37(12): 1875-1884.]

[28] 王姣娥, 焦敬娟, 黄洁, 等. 交通发展区位测度的理论与方法. 地理学报, 2018, 73(4): 666-676. [WANG J E, JIAO J J, HUANG J, et al. Theory and methodology of transportation development and location measures. Acta Geographica Sinica, 2018, 73(4): 666-676.]

[29] 刘安乐, 杨承玥, 鲁芬, 等. 滇中城市群交通网络与旅游业耦合发展研究. 世界地理研究, 2017, 26(1): 65-76. [LIU A L, YANG C Y, LU F, et al. Study on coordinated development of transportation network and tourism in central Yunnan urban agglomeration. World Regional Studies, 2017, 26(1): 65-76.]

[30] 王峰. 西南边疆山区交通网络与旅游空间结构演化关联机制及效应研究: 以云南省为例. 上海: 华东师范大学, 2014. [WANG F. Relationship mechanism and effect of transportation network and tourism spatial structure evolution in southwestern mountainous areas: A case study of Yunnan province. Shanghai: East China Normal University, 2014.]

[31] TIAN S Z, LI X M, YANG J, et al. Initial study on triaxiality of human settlements: In the case of 10 districts (counties) of Dalian. Sustainability, 2014, 6(10): 7276-7291.

[32] 郭向阳, 穆学青, 明庆忠, 等. 旅游地快速交通优势度与旅游流强度的空间耦合分析. 地理研究, 2019, 38(5): 11191135. [GUO X Y, MU X Q, MING Q Z, et al. Spatial coupling between rapid traffic superiority degree and tourist flow intensity in tourist destinations. Geographical Research, 2019, 38(5): 1119-1135.]

[33] 匡丽花, 叶英聪, 赵小敏, 等. 基于改进 TOPSIS 方法的耕地系统安全评价及障碍因子诊断. 自然资源学报, 2018, 33 (9): 1627-1641. [KUANG L H, YE Y C, ZHAO X M, et al. Evaluation and obstacle factor diagnosis of cultivated land system security in Yingtan city based on the improved TOPSIS method. Journal of Natural Resources, 2018, 33(9): 1627-1641.] 
[34] 肖黎明, 张仙鹏. 强可持续理念下绿色创新效率与生态福利绩效耦合协调的时空特征. 自然资源学报, 2019, 34(2): 312-324. [XIAO L M, ZHANG X P. Spatio-temporal characteristics of coupling coordination between green innovation efficiency and ecological welfare performance under the concept of strong sustainability. Journal of Natural Resources, 2019, 34(2): 312-324.]

[35] 金风君, 王成金, 李秀伟. 中国区域交通优势的甄别方法及应用分析. 地理学报, 2008, 63(8): 787-798. [JIN F J, WANG C J, LI X W. Discrimination method and its application analysis of regional transport superiority. Acta Geographica Sinica, 2008, 63(8): 787-798.]

[36] 王成新, 王格芳, 刘瑞超, 等. 区域交通优势度评价模型的建立与实证: 以山东省为例. 人文地理, 2010, 25(1): 7376. [WANG C X, WANG G F, LIU R C, et al. Empirical research on evaluation model of transport superiority degree: A case study of Shandong province. Human Geography, 2010, 25(1): 73-76.]

[37] 陈浩, 陆林, 郑嬗婷. 珠江三角洲城市群旅游空间格局演化. 地理学报, 2011, 66(10): 1427-1437. [CHEN H, LU L, ZHENG S T. The tourism spatial pattern evolution of the Pearl River Delta. Acta Geographica Sinica, 2011, 66(10): 1427-1437.]

[38] 秦伟山, 张义丰, 李世泰. 中国东部沿海城市旅游发展的时空演变. 地理研究, 2014, 33(10): 1956-1965. [QIN W S, ZHANG Y F, LI S T. Study on the spatio-temporal evolution of coastal city tourism of China. Geographical Research, 2014, 33(10): 1956-1965.]

[39] 曹芳东, 黄震方, 吴江. 转型期城市旅游业绩效评价及空间格局演化机理: 以泛长江三角洲地区为例. 自然资源学 报, 2013, 28(1): 148-160. [CAO F D, HUANG Z F, WU J. Evaluation on urban tourism industry performance and formation mechanism of pattern evolution during the transition period: A case study of the Pan-Yangtze River Delta. Journal of Natural Resources, 2013, 28(1): 148-160.]

[40] 穆学青, 郭向阳, 明庆忠. 边境地区旅游强度时空演化特征分析. 经济地理, 2019, 39(1): 233-240. [MU X Q, GUO X Y, MING Q Z. Temporal and spatial evolutionary characteristics of tourism intensity in the border areas. Economic Geography, 2019, 39(1): 233-240.]

[41] 谢彦君. 基础旅游学. 北京: 商务印书馆, 2015: 279-305. [XIE Y J. Basic Tourism. Beijing: The Commercial Press, 2015: 279-305.]

[42] 刘军胜, 马耀峰. 基于发生学与系统论的旅游流与目的地供需耦合成长演化与驱动机制研究: 以西安市为例. 地理 研究, 2016, 36(8): 1583-1600. [LIU J S, MA Y F. The evolution and driving mechanism of the supply and demand coupling about tourism flow and destination system based on the genesis and system theory: Taking Xi'an as an example. Geographical Research, 2016, 36(8): 1583-1600.]

[43] 张子昂, 黄震方, 曹芳东, 等. 浙江省县域人境旅游时空跃迁特征及驱动机制. 地理研究, 2016, 35(6): 1177-1192. [ZHANG Z A, HUANG Z F, CAO F D, et al. The space-time transition characteristics and its driving mechanism of county-scale inbound tourism in Zhejiang province. Geographical Research, 2016, 35(6): 1177-1192.]

[44] 曹芳东, 黄震方, 徐敏, 等. 风景名胜区旅游效率及其分解效率的时空格局与影响因素: 基于 Bootstrap-DEA 模型的 分析方法. 地理研究, 2015, 34(12): 2395-2408. [CAO F D, HUANG Z F, XU M, et al. Spatial-temporal pattern and influencing factors of tourism efficiency and the decomposition efficiency in Chinese scenic areas: Based on the Bootstrap-DEA method. Geographical Research, 2015, 34(12): 2395-2408.]

[45] LIU Y P, LI Y C, PARKPIAN P. Inbound tourism in Thailand: Market form and scale differentiation in ASEAN source countries. Tourism Management, 2018, 64(1): 22-36.

[46] 明庆忠, 童绍玉. 云南地理. 北京: 北京师范大学出版社, 2016: 3-195. [MING Q Z, TONG S Y. Yunnan Geography. Beijing: Beijing Normal University Press, 2016: 3-195.]

[47] GAO Y Y, SU W, WANG K N. Does high-speed rail boost tourism growth?. New evidence from China. Tourism Management, 2019, 72(6): 220-231.

[48] 李否, 孙小龙, 陆林, 等. 国内外高铁旅游研究热点、进展及启示. 世界地理研究, 2019, 28(1): 175-186. [LI L, SUN X L, LU L, et al. The hotspots, progress and inspiration of high-speed rail tourism research. World Regional Studies, 2019, 28(1): 175-186.] 


\title{
Spatial and temporal differentiation characteristics of transportation service function and tourism intensity coordination: A case study of Yunnan province
}

\author{
GUO Xiang-yang ${ }^{1,2}$, MU Xue-qing ${ }^{3}$, MING Qing-zhong ${ }^{4}$, DING Zheng-shan ${ }^{1,2}$ \\ (1. School of Geography Science, Nanjing Normal University, Nanjing 210023, China; 2. Jiangsu Center for \\ Collaborative Innovation in Geographical Information Resource Development and Application, Nanjing 210023, \\ China; 3. College of Tourism and Geography, Yunnan Normal University, Kunming 650500, China; 4. Institute \\ of Tourism and Culture Industry, Yunnan University of Finance and Economics, Kunming 650221, China)
}

\begin{abstract}
Taking the typical tourist destination-Yunnan province as a research case, and based on the multi-source data such as Gaode traffic big data and electronic map POI, this study uses the improved TOPSIS method, coupled coordination model and Tobit model to construct the comprehensive traffic service function and tourism intensity conceptual model. From the perspective of time and space, this paper examines the spatial differentiation characteristics of transportation service function and tourism intensity coordination and the contribution of different transportation service functions to tourism intensity. The results show that: (1) From 2006 to 2016, the synergy effect of comprehensive transportation service functions and tourism intensity in various cities of Yunnan province became more prominent, and the type of coordination leading has changed from "official disorder" to "primary coordination type". (2) The overall pattern of comprehensive transportation service functions and tourism intensity coordination degree shows a pattern of "high in the middle, but low in the east and west as well as in the north and south", and the east and west are greatly divided, and the north- south changes are relatively stable. The regional differences within the province are characterized by "Central part $>$ Southeast $>$ Southwest $>$ West $>$ Northwest $>$ Northeast". There is a significant difference in the spatial differentiation characteristics of different types of transportation modes and tourism intensity coordination. (3) The contribution of roads, railways and aviation lines to tourism intensity is characterized by the unbalance of "air transportation $>$ road traffic $>$ railway traffic". The income of tourism residents, the endowment of tourism resources and the degree of marketization all have positive effects on tourism intensity. However, the lower level of opening up has restricted the improvement of regional tourism intensity to a certain extent.
\end{abstract}

Keywords: multi- source data; transportation service function; tourism intensity; coupling coordination model; Yunnan province 